Article

\title{
Nanocomposite of Si/C Anode Material Prepared by Hybrid Process of High-Energy Mechanical Milling and Carbonization for Li-Ion Secondary Batteries
}

\author{
Reddyprakash Maddipatla, Chadrasekhar Loka, Woo Jeong Choi and Kee-Sun Lee * \\ Department of Advanced Materials Engineering, Kongju National University, Cheonan 31080, Korea; \\ prakashnaidu50@gmail.com (R.M.); csloka89@gmail.com (C.L.); qpzzz@kongju.ac.kr (W.J.C.) \\ * Correspondence: kslee@kongju.ac.kr
}

Received: 30 September 2018; Accepted: 30 October 2018; Published: 2 November 2018

\begin{abstract}
Si/C nanocomposite was successfully prepared by a scalable approach through high-energy mechanical milling and carbonization process. The crystalline structure of the milled powders was studied using X-ray diffraction (XRD) and transmission electron microscopy (TEM). Morphology of the milled powders was investigated by Field-emission scanning electron microscopy (FE-SEM). The effects of milling time on crystalline size, crystal structure and microstructure, and the electrochemical properties of the nanocomposite powders were studied. The nanocomposite showed high reversible capacity of $\sim 1658 \mathrm{mAh} / \mathrm{g}$ with an initial cycle coulombic efficiency of $\sim 77.5 \%$. The significant improvement in cyclability and the discharge capacity was mainly ascribed to the silicon particle size reduction and carbon layer formation over silicon for good electronic conductivity. As the prepared nanocomposite $\mathrm{Si} / \mathrm{C}$ electrode exhibits remarkable electrochemical performance, it is potentially applied as a high capacity anode material in the lithium-ion secondary batteries.
\end{abstract}

Keywords: silicon/carbon nanocomposite; lithium-ion battery; high-energy mechanical milling; anode materials

\section{Introduction}

Rechargeable lithium-ion batteries (LIBs) are widely used as state-of-the-art energy storage systems due to their large volumetric and gravimetric energy densities. However, further improvement is necessary in the energy densities of LIBs to satisfy the ever-growing demands for portable electronic devices (especially cell phones, notebook computers, and digital cameras), electric vehicles, and renewable energy storage systems (such as for wind energy and solar energy) [1-4]. Currently, graphite is used as the conventional anode material for commercial LIBs systems. Since it has limited theoretical capacity of $372 \mathrm{mAh} \mathrm{g}^{-1}$ [5], anode materials with high capacity have attracted considerable attention. Silicon shows greater advantages than the any other known anode materials owing to its attractive features such as extremely high theoretical capacity ( $3579 \mathrm{mAh} \mathrm{g}^{-1}$ for $\mathrm{Li}_{15} \mathrm{Si}_{4}$ at room temperature), low lithiation/delithiation voltage, non-toxicity, and natural abundance [6,7]. However, silicon suffers from detrimental huge volume changes ( 300\%) during the lithium insertion/extraction process, which lead to pulverization and formation of unstable solid electrolyte interface (SEI) and poor conductive network, eventually leading to rapid capacity fading and poor cyclability [8-10]. Therefore, huge volume expansion and low intrinsic electronic conductivity hinder its practical usage as an anode material [11]. The practical application of Si-based anodes in lithium ion full cells (not tested in a half cell setup vs. lithium metal) is the loss of active lithium from the cathode due to ongoing SEI formation [12]. Various approaches have been reported to resolve this problem: (1) designing of nanostructured silicon (such as nanoparticles, nanowires, nanotubes, thin films [13-16], and porous structures [17]) to decrease the volume change; and (2) designing and fabrication of 
Si-based composite structures in which nano-sized Si uniformly dispersed in the active or inactive materials (metal oxides, metal alloys and conductive polymers) to accommodate the Si volume expansion/contraction [18-21]. Moreover, many attempts have been made to use suitable binders, electrolyte additives, and current collector [22-24]. Among them, silicon/carbon composites (such as Si-graphite, Si-graphene, Si-disordered carbon, Si-carbon nanotubes, and Si-carbon aerogel) have been demonstrated as an efficient approach for enhancing the electrochemical performance [25-29] because the carbon layer can improve the electronic conductivity of the composite and it can accommodate the volume changes of Si during the cycling.

Several synthesis methods are employed for the preparation of $\mathrm{Si} / \mathrm{C}$ composite anode. Among them, there are five representative methods: chemical/thermal vapor deposition [30] or pyrolysis [31], mechanical milling [32], mechanical milling and pyrolysis [33], chemical reaction of gel [34], and dehydration of a carbon precursor [35]. Excluding the above methods, the combination of high-energy mechanical milling (HEMM) and subsequent carbonization process is supposed to yield a finely dispersed nanocomposite materials and also has an advantageous for the mass-production due to its low-cost and operation simplicity. HEMM is not only for fragmenting, but also enables good mixing of the composite powder. Consequently, homogeneously mixed composite powders can be obtained [36]. In this paper, we present a carbon-impregnated Si nanocomposite by a scalable approach of high-energy mechanical milling and carbonization process, in which the nano-sized silicon is besieged with carbon. This structure is expected to improve the cyclic performance because the carbon impregnation can offer the desired mechanical stability and stabilize the solid electrolyte interface layers (SEI), contributing to enhancing the electronic conductivity. Consequently, this research paper covers the $\mathrm{Si} / \mathrm{C}$ nanocomposite preparation, investigation of the changes in crystal structure and morphology, and evaluation of their electrochemical properties.

\section{Experimental Details}

\subsection{Preparation of Si/C Nanocomposite}

\subsubsection{Preparation of Nano-Scale Si Powder}

The nano-scale Si powder was synthesized from commercially obtained micro-sized $(\sim 100 \mu \mathrm{m}) \mathrm{Si}$ powder by a high-energy mechanical milling system (Simoloyer CM01, Zoz GmbH, Wenden, Germany) controlled by MALTOZ-software (Zoz GmbH, Wenden, Germany). The milling was carried out in an Argon gas filled stainless steel jar (chamber) containing stainless steel balls (diameter $\sim 5 \mathrm{~mm}$ ) as milling media. The weight ratio of stainless-steel balls to powder was 15:1. The stearic acid ( $5 \mathrm{wt} \%$ of total Si weight) was used as a processing control agent to avoid the agglomeration and contamination caused by balls and jar. The silicon powders were milled for $8 \mathrm{~h}$ with the milling conditions of impeller speed of $1300 \mathrm{rpm}$ for the first $45 \mathrm{~s}$ and $700 \mathrm{rpm}$ for the next $15 \mathrm{~s}$ to achieve a homogeneous nano-scale Si powder.

\subsubsection{Fabrication of $\mathrm{Si} / \mathrm{C}$ Nanocomposite}

Citric acid $\left(\mathrm{C}_{6} \mathrm{H}_{8} \mathrm{O}_{7}\right.$, Daejung chemical Co., Ltd., Siheung, Gyonggi-do, Korea) and propylene glycol $\left(\mathrm{CH}_{3} \mathrm{CH}(\mathrm{OH}) \mathrm{CH}_{2} \mathrm{OH}\right.$, Samchun pure Chemical Co., Ltd., Pyeongtaek, Gyonggi-do, Korea) were used to prepare the carbon solution. A typical carbon solution was formed by mixing of $50 \mathrm{wt} \%$ of citric acid and $50 \mathrm{wt} \%$ propylene glycol using the magnetic stirring for $7 \mathrm{~h}$. Subsequently, the carbon solution was added to the produced silicon powders in the weight ratio (Carbon solution:Si) of 10:20. After that, the resulting mixture was heat-treated at $900{ }^{\circ} \mathrm{C}$ in a horizontal quartz tube furnace for $1 \mathrm{~h}$ in the Argon ambient for the carbonization to form the $\mathrm{Si} / \mathrm{C}$ composite. The ramp rate was $10^{\circ} \mathrm{C} / \mathrm{min}$, and $\mathrm{Ar}$ gas flow rate was maintained at $2.5 \mathrm{~L} / \mathrm{min}$. The carbon coated silicon powders were again milled for $8 \mathrm{~h}$ under the same milling conditions. Thus, the final $\mathrm{Si} / \mathrm{C}$ nanocomposite anode materials were obtained. 


\subsection{Characterization and Electrochemical Test}

The distribution of particle size of the $\mathrm{Si}$ and $\mathrm{Si} / \mathrm{C}$ composite powder synthesized by HEMM and carbonization was determined by laser diffraction particle size analyzer SALD-2300 (Shimadzu Corp., Kyoto, Japan). Crystallinity of the powders was studied by X-ray diffractometer (Mini flex 600, rigaku) with $\mathrm{Cu}-\mathrm{K} \alpha$ radiation $(\lambda=0.15418 \mathrm{~nm})$ operated at $600 \mathrm{~W}$ over the $2 \theta$ range of $10-70^{\circ}$. The morphology and microstructures of the as-milled powders and the cycled electrodes were examined by field-emission scanning electron microscopy (FE-SEM; MIRA3, TESCAN, Brno-Kohoutovice, Czech Republic) and transmission electron microscopy (TEM; JEM-ARM200F, JEOL Ltd., Tokyo, Japan).

For the evaluation of electrochemical characteristics, the composite electrodes were prepared by coating on the copper ( $\mathrm{Cu}$ foil, Wellcos Co., Ltd., Gunpo-si, Gyeonggi-do, Korea) substrate using a blade coater with slurry consisted of $80 \mathrm{wt} \%$ active material, $10 \mathrm{wt} \%$ of SFG6 graphite (Sigma-Aldrich, Yongin-si, Gyeonggi-do, Korea) and 2 wt \% of Ketjenblack (Sigma-Aldrich) as conductive agents, and $8 \mathrm{wt} \%$ of poly acrylic acid (PAA, $\mathrm{Mw}=250,000$, Sigma-Aldrich) as binder materials, which were dissolved in DI water. The screen-printed electrodes were dried at $100{ }^{\circ} \mathrm{C}$ for $10 \mathrm{~min}$. After drying, they were cut into 16-mm diameter discs and subsequently, heat-treated at $100{ }^{\circ} \mathrm{C}$ for $6 \mathrm{~h}$ under vacuum. The electrochemical test was performed using coin cells (half-cells). The CR-2032 coin-type cells were assembled in a high-purity argon (99.99\%) filled glove box. Lithium foil was used as both the counter and reference electrodes. The Celgard 2400 was used as the separator. A solution of one molar lithium hexafluorophosphate ( $\mathrm{LiPF}_{6}$, PANAX ETEC Co. Ltd, Busan, Korea, purity: 99.9\%) dissolved in a solvent mixture of ethylene carbonate (EC)/ diethyl carbonate (DEC)/ fluoroethylene carbonate (FEC) (5:70:25 by volume) was used as electrolyte. Cyclic voltammetry test for the cells was performed using ZIVE MP1 potentiostat analyzer system (ZIVE MP1, WonATech Corp., Seoul, Korea) with a cut-off potential ranges of $0.01-1.5 \mathrm{~V}$ (at constant current density of $2.8 \mathrm{~mA} \mathrm{~cm}^{-2}$ ) at 0.1 and $0.2 \mathrm{C}$-rate for the first and second cycles, respectively, and 1.0 C-rate from the third cycle. All the electrochemical tests were conducted at room temperature. The EIS (electrochemical impedance spectroscopy) measurements were carried out for $\mathrm{Si} / \mathrm{C}$ nanocomposite powder with an impedance analyzer (ZIVE MP1, WonATech Corp., Seoul, Korea) over a frequency range from $100 \mathrm{kHz}$ to $10 \mathrm{mHz}$.

\section{Results and Discussion}

The X-ray diffraction patterns of as milled Si powder at various milling times are shown in Figure 1a. The diffraction peaks of all the powders are matching with JCPDS (Joint Committee on Powder Diffraction Standards) Card file 27-1402. Comparing to the starting silicon powders, the milled Si powder diffraction peak intensities are obviously decreased and broadened with respect to milling time, which indicates the pulverization of the Si powder and decrease of the Si crystal size during the mechanical milling. The change in Si crystal size was saturated by $8 \mathrm{~h}$ milling, which was the first step for the nano-crystalline Si/C composite powders. The Si powders were followed by the mixing with carbon solution and heat treatment at $900^{\circ} \mathrm{C}$ for $1 \mathrm{~h}$ in $\mathrm{Ar}$ ambient (carbonization process). Through the carbonization, the $\mathrm{Si} / \mathrm{C}$ composite powder was produced and additionally milled at different milling times and their diffraction patterns are shown in Figure $1 \mathrm{~b}$. The Si peak intensities were slightly increased, compared with $8 \mathrm{~h}$-milled Si powder (the first step), which was due to partial recovery of the Si crystallinity. No graphite carbon peaks were observed, which was presumed to be amorphous phase carbon. However, the additional milling drastically deceased intensities of the Si diffraction peaks with severe background broadening. Since such X-ray diffraction results are correlated with a marked reduction in the crystal size and loss of crystallinity, it was believed that $\mathrm{Si}$ powders were reduced, and their crystallinity ceaselessly collapsed. In even $8 \mathrm{~h}$-milling, no peaks such as $\mathrm{Fe}, \mathrm{SiC}$ and $\mathrm{SiO}_{2}$ were detected, which indicated the contamination driven by the mechanical milling was not serious. 

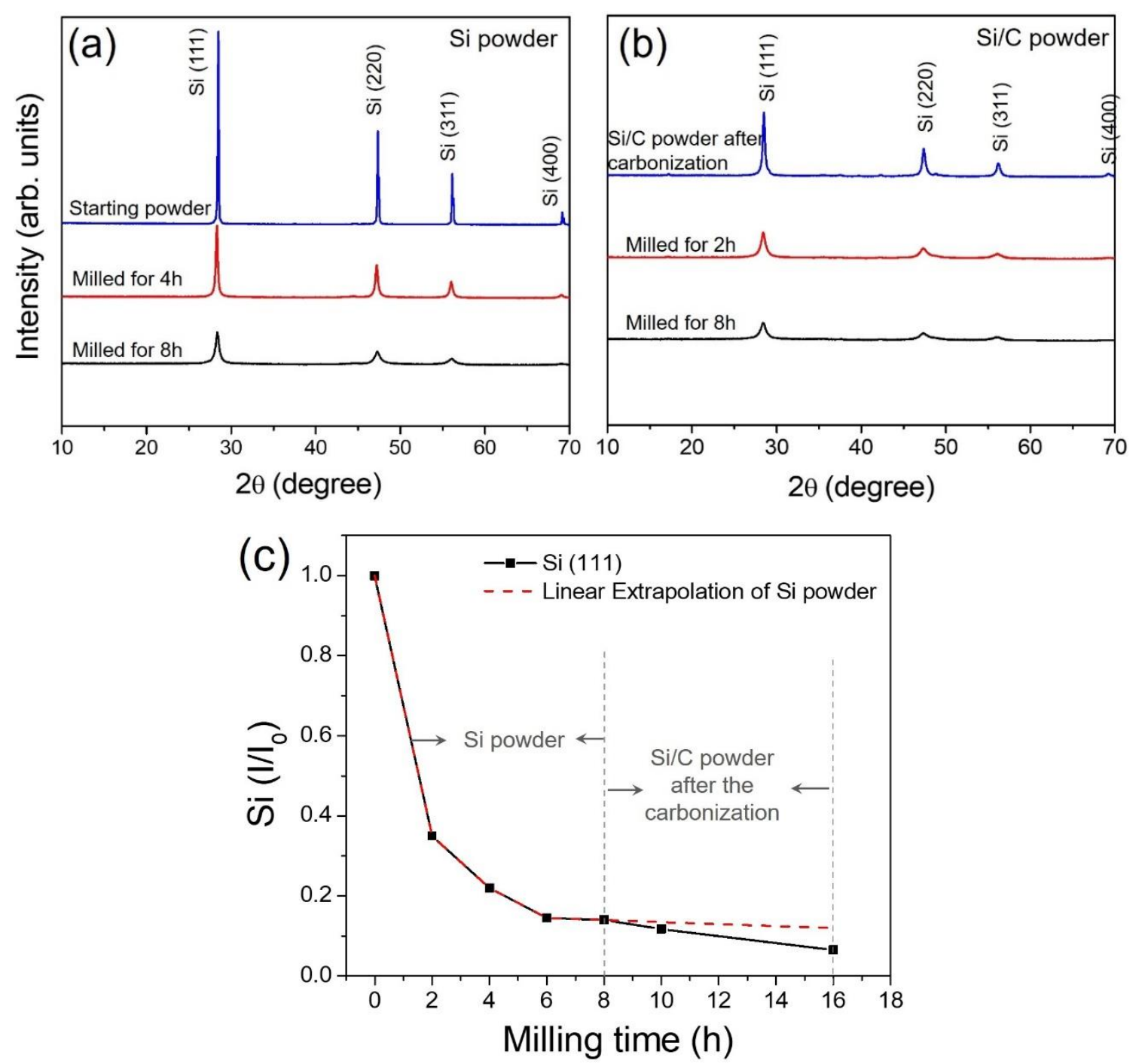

Figure 1. X-ray diffraction patterns of the Si and Si/C composite powders: (a) Si powder; (b) Si/C nanocomposite powder; and (c) change in intensity ratio of the Si peak before and after the carbonization with respect to milling time.

The normalized Si (111) peak intensity changes in the $\mathrm{Si}$ and $\mathrm{Si} / \mathrm{C}$ composite powders were studied with respect to milling time, as shown in Figure 1c. A rapid decline in the Si peak intensity ratio was observed within the first $8 \mathrm{~h}$ of the high-energy mechanical milling; further milling up to $8 \mathrm{~h}$ showed less influence on the intensity ratio. The linear extrapolation of the Si powder with respect to milling time appeared to be almost flat without any significant reduction in the intensity ratio, as shown in Figure 1c, indicating that $8 \mathrm{~h}$ is the critical milling time for effective pulverization of the $\mathrm{Si}$ powders. However, a ceaseless decrease in intensity ratio of the $\mathrm{Si} / \mathrm{C}$ powder (carbonized and additionally milled) was observed, indicating that further fragmentation of Si crystals occurred in the type of the $\mathrm{Si} / \mathrm{C}$ powder. Thus, the extended milling (i.e., $8 \mathrm{~h}$ ) for the $\mathrm{Si} / \mathrm{C}$ was believed to be effective to obtain the $\mathrm{Si} / \mathrm{C}$ nanocomposite.

The starting silicon powder was composed of unevenly distributed irregular particles with size ranging 50-100 $\mu \mathrm{m}$ (Figure 2a). In the case of $8 \mathrm{~h}$ milled silicon, the powder size was significantly decreased, and distributed in the range of 100-500 $\mathrm{nm}$ (Figure $2 \mathrm{~b}$ ), which was estimated from the particle size distribution analysis (Table 1 ). The $\mathrm{Si} / \mathrm{C}$ composite powder size increased after the carbonization at $900{ }^{\circ} \mathrm{C}$, and agglomerated powders were observed (Figure 2c). The Si powders were connected during the carbonization and resulted in the agglomeration. However, as shown in 
Figure $2 \mathrm{~d}$, further milling for $8 \mathrm{~h}$ changed the $\mathrm{Si} / \mathrm{C}$ powders into very fine $\mathrm{Si} / \mathrm{C}$ nanocomposite powder with comparatively more uniform distribution than that of $\mathrm{Si} / \mathrm{C}$ powder without milling. The particles sizes are in the rage of 100-200 $\mathrm{nm}$. This observation suggests that the hybrid process of high-energy milling and carbonization is an effective approach to synthesize the $\mathrm{Si} / \mathrm{C}$ nanocomposite powders.
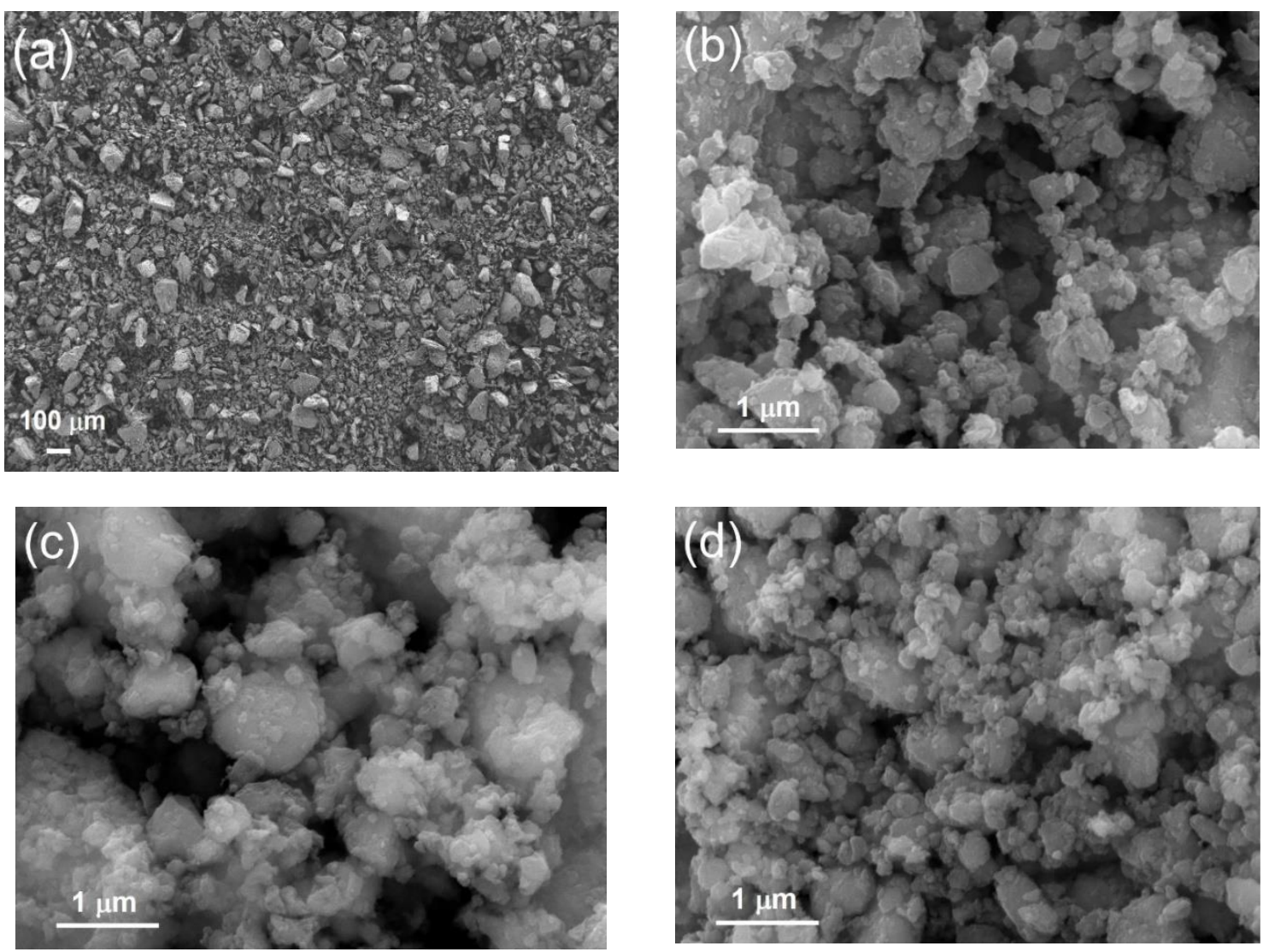

Figure 2. FE-SEM images of the Si and Si/C composite powders: (a) Si raw powder; (b) Si milled for $8 \mathrm{~h}$; (c) Si/C powder after carbonization; and (d) Si/C milled for $8 \mathrm{~h}$.

Table 1. Average particle size and standard deviation of the as milled Si and Si/C powders.

\begin{tabular}{ccc}
\hline Sample Name & Average Particle Size $\mathbf{( n m )}$ & Standard Deviation $(\mathbf{n m})$ \\
\hline Si-8 h milling & 250 & 79 \\
Si/C composite & 350 & 138 \\
Si/C-8 h milling & 200 & 61 \\
\hline
\end{tabular}

The charge-discharge voltage curves of the $\mathrm{Si} / \mathrm{C}$ nanocomposite for the 1st, 3rd, 10th, 20th, and 50th cycles are presented in Figure 3a. The electrode delivers first cycle charge and discharge capacities of 2139 and $1658 \mathrm{mAh} \mathrm{g}^{-1}$, respectively, corresponding to a first cycle coulombic efficiency of $77.5 \%$. Similarly, for the 50th cycle charge and discharge, capacities are 1267 and $1278 \mathrm{mAh} \mathrm{g}^{-1}$ respectively, with a coulombic efficiency of $99.13 \%$. The irreversible capacity loss of the electrode during $1 \mathrm{st}$, 3rd, 10th, 20th and 50th cycles are $22.5 \%, 7 \%, 0.9 \%, 0.8 \%$ and $0.87 \%$, respectively. The first and third cycle irreversible capacity losses are higher, which could be caused by the side reactions with electrolyte and formation of a solid electrolyte interface layer on the electrode surface accompanied by the consumption of lithium [37,38]. Therefore, coulombic efficiency after the third cycle attained $~ 99 \%$ within five cycles. A long and flat discharge voltage plateau observed during the first cycle at below $0.2 \mathrm{~V}$ indicates the lithiation of crystalline Si transforms into amorphous $\mathrm{Li}_{x} \mathrm{Si}$ phase and the formation of SEI [39]. Figure $3 \mathrm{~b}$ shows the discharge capacities and coulombic efficiency of $\mathrm{Si} / \mathrm{C}$ nanocomposite electrode 
with respect to cycle number. The initial cycle discharge capacity of the electrode is $1658 \mathrm{mAh} \mathrm{g}^{-1}$ at $0.1 \mathrm{C}$-rate. The composite electrode exhibited monotonous capacity fading, good reversible capacity and excellent capacity retention from the 5th to 100th cycle. However, a moderate capacity fading during the initial cycle was observed. Remarkably, the coulombic efficiencies of the electrodes after fifth cycle were steadily saturated with an efficiency of $\sim 99.1 \%$. The nano-sized active materials affect the electrochemical stability in view of available surface area and shortening the Li-ion diffusion path; all of these factors are contributed to observed cyclability [40,41]. Moreover, the amorphous carbon matrix can stabilize $\mathrm{Si}$ volume change and offer the diffusion path of lithium ions toward the active $\mathrm{Si}$ phase during the Li-alloying/dealloying process. It has been reported that carbon is beneficial to not only buffer the volume changes during the cycling process, but also to avoid agglomeration of the silicon particles [42]. We have further compared our results with other reported $\mathrm{Si} / \mathrm{C}$ based anode materials. Among them, our material shows good capacity retention and high reversible capacity values even after 100 th cycle at $1 \mathrm{C}$ rate (Table 2).
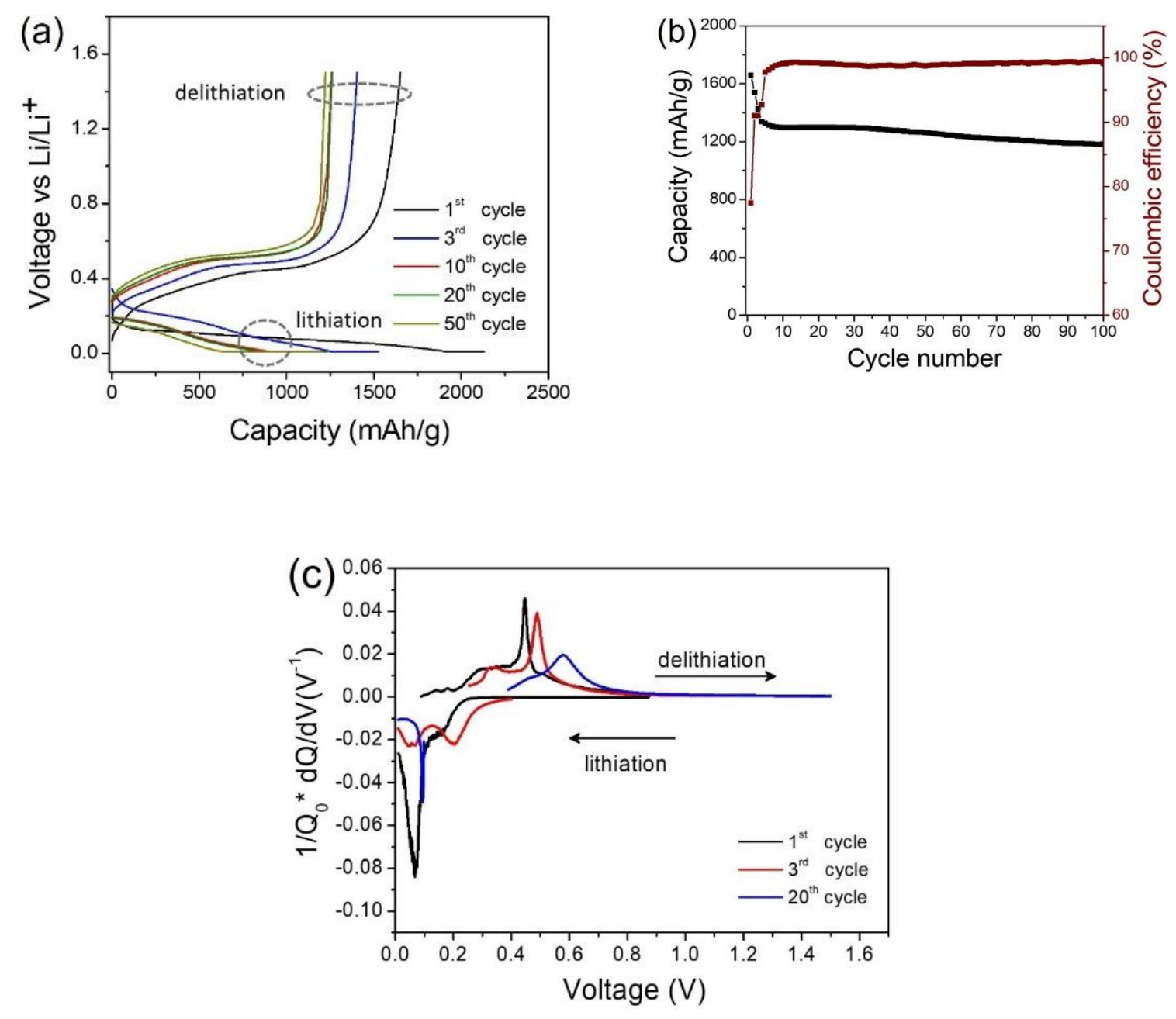

Figure 3. Electrochemical characteristics of the coin-type half cells produced by $8 \mathrm{~h}$ milled Si/C nanocomposite powders: (a) potential vs. lithiation/delithiation curves; (b) discharge capacity and coulombic efficiency; and (c) differential capacity plot for 1st, 3rd, and 20th cycle. 
Table 2. Electrochemical performance of the Silicon/Carbon based anode materials for Li-ion secondary batteries (capacity retention for 100th cycle was calculated based on the first cycle reversible capacity).

\begin{tabular}{|c|c|c|c|c|c|c|}
\hline Sample Name & $\begin{array}{l}\text { Weight Ratio of Active } \\
\text { Material in Electrode }\end{array}$ & 1st Discharge Capacity & $\begin{array}{l}\text { 1st Coulombic } \\
\text { Efficiency }\end{array}$ & Cyclic Stability & $\begin{array}{l}\text { Capacity } \\
\text { Retention }\end{array}$ & Ref. \\
\hline $\mathrm{Si} / \mathrm{C}$ nanocomposite & $80 \%$ & $1658 \mathrm{mAh} / \mathrm{g}($ at $0.1 \mathrm{C})$ & $77.5 \%$ & $\begin{array}{c}1181 \mathrm{mAh} / \mathrm{g}(\text { at } 1 \mathrm{C}) \text { after } \\
100 \text { cycles }\end{array}$ & $71.2 \%$ at 100 th cycle & In this work \\
\hline $\begin{array}{l}\text { Si/graphite } \\
\text { composite }\end{array}$ & $80 \%$ & $\begin{array}{c}1533 \mathrm{mAh} / \mathrm{g} \text { (at } 0.2 \\
\mathrm{~A} / \mathrm{g})\end{array}$ & $72.4 \%$ & $\begin{array}{c}665 \mathrm{mAh} / \mathrm{g}(\text { at } 0.2 \mathrm{~A} / \mathrm{g}) \\
\text { after } 100 \text { cycles }\end{array}$ & $43.3 \%$ at 100 th cycle & [18] \\
\hline Si/C composite & $80 \%$ & $\begin{array}{c}1387 \mathrm{mAh} / \mathrm{g} \text { (at } 0.2 \\
\mathrm{~A} / \mathrm{g})\end{array}$ & $82.5 \%$ & $\begin{array}{c}678 \mathrm{mAh} / \mathrm{g}(\text { at } 0.2 \mathrm{~A} / \mathrm{g}) \\
\text { after } 100 \text { cycles }\end{array}$ & $49.2 \%$ at 100 th cycle & [18] \\
\hline $\mathrm{Si} / \mathrm{C}$ nanocomposite & $80 \%$ & $\begin{array}{c}2600 \mathrm{mAh} / \mathrm{g} \text { (at } 0.1 \\
\mathrm{~A} / \mathrm{g})\end{array}$ & $71 \%$ & $\begin{array}{c}1120 \mathrm{mAh} / \mathrm{g}(\text { at } 0.1 \mathrm{~A} / \mathrm{g}) \\
\text { after } 100 \text { cycles }\end{array}$ & $43 \%$ at 100 th cycle & [42] \\
\hline $\mathrm{Si} / \mathrm{C}$ nanocomposite & $80 \%$ & $\begin{array}{c}1561 \mathrm{mAh} / \mathrm{g} \text { (at } 0.15 \\
\left.\mathrm{~mA} / \mathrm{cm}^{2}\right)\end{array}$ & $61.9 \%$ & $\begin{array}{c}626 \mathrm{mAh} / \mathrm{g} \text { (at } \\
\left.0.15 \mathrm{~mA} / \mathrm{cm}^{2}\right) \text { after } \\
30 \mathrm{cycles}\end{array}$ & $40.1 \%$ at 30 th cycle & [43] \\
\hline
\end{tabular}


The differential capacity plots (DCPs) during the 1st, 3rd, and 20th cycles of the $\mathrm{Si} / \mathrm{C}$ nanocomposite electrodes are shown in Figure 3c. The intense peak observed at $0.067 \mathrm{~V}$ of the first cycle corresponds to the lithiation of crystalline $\mathrm{Si}$ to form an amorphous $\mathrm{Li}_{\mathrm{x}} \mathrm{Si}$ alloy $[44,45]$. In the case of third cycle, two peaks were observed at $0.06 \mathrm{~V}$ and $0.2 \mathrm{~V}$ belonging to the phase transition process of the $\mathrm{Li}_{x} \mathrm{Si}$. A single peak observed at $0.087 \mathrm{~V}$ in the higher order cycles, i.e., 20th cycle, represent a stable SEI formation and constant lithiation or alloying process of the amorphous $\mathrm{Si}$ with $\mathrm{Li}$. The pure Si exhibits a peak at $0.45 \mathrm{~V}$, indicating the de-alloying of lithium during the first cycle discharge [46]. Beyond the first cycle, two broad peaks at 0.52 and $0.55 \mathrm{~V}$ during the delithiation process were observed. The two broad peaks indicate the conversion of crystalline silicon to an amorphous state after the first cycle. Datta et al. and Wang et al. reported that the peaks obtained at high-voltage delithiation $(0.35-0.5 \mathrm{~V})$ are attributed to the amorphous Li-Si alloys and the formation of amorphous silicon $[47,48]$. In addition, Sourice et al. reported that the lithiation peak observed at $0.05 \mathrm{~V}$ after the first cycle ascribed to crystallization of the $\mathrm{Li}_{3.75} \mathrm{Si}$ phase [49]. However, in the case of extended cycles at 20th cycle, the peak appeared at $0.1 \mathrm{~V}$ due to the amorphization process of Si during the initial cycles. Even though the Si is progressively amorphized, the curve area gets increased at the extended cycling 20th cycle represent more $\mathrm{Si}$ is activated in the alloying/dealloying reactions.

TEM images of the Si/C nanocomposite electrode are shown in Figure 4a,b. The selected area electron diffraction (SAED) patterns show the Si (111) and (220) planes. From high-resolution TEM image, the lattice inter-planar distance (d-spacing) was calculated for $\mathrm{Si}$, and the d-spacing was $\sim 0.32 \mathrm{~nm}$, which is corresponding to the $\mathrm{Si}$ (111) plane. It has been observed that the nanocomposite was comprised of nanocrystalline $\mathrm{Si}$, amorphous $\mathrm{Si}$ and amorphous carbon. The nanocrystalline $\mathrm{Si}$ was distributed on the amorphous silicon and carbon matrix. The amorphous Si phase could also be formed due to amorphization of Si (supported by background broadening in the X-ray diffraction results) for the longer mechanical milling. Amorphous carbon phase could be produced in the form of interface between Si powders and coating on the Si powders from the heat treatment of the citric acid (carbonization). In addition, carbon was expected to diffuse into the Si crystals through surface and boundary diffusion. Such an impregnation of the carbon is believed to be effective to both improve the milling efficiency (refinement of Si crystal size) and act as a mechanically strong (highly elastic) buffering matrix against the $\mathrm{Si}$ volume change. However, as shown in Figure 4c, the HR (High resolution)-TEM image of the $\mathrm{Si} / \mathrm{C}$ nanocomposite electrode at the 100th cycle, a complete amorphization of the nanocomposite powder was observed, which could be due to the stress generated by the Si during the lithiation and delithiation due to extended cycling.
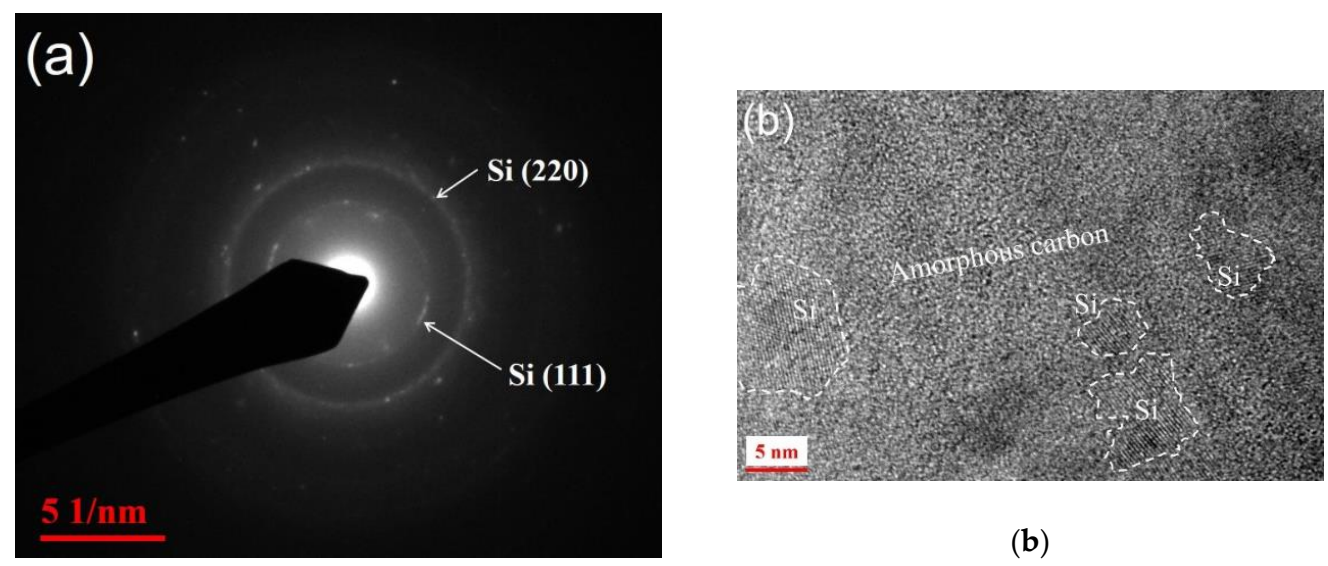

(b)

(a)

Figure 4. Cont. 


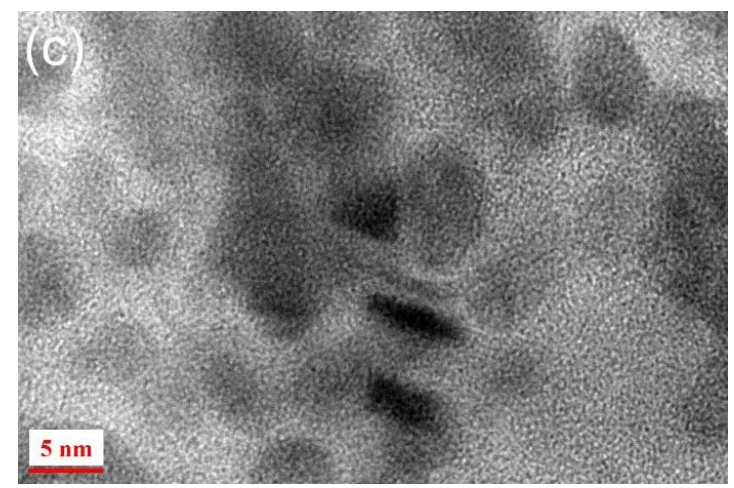

Figure 4. (a) Selected area electron diffraction (SAED) pattern; (b) HR (High resolution)-TEM image of Si/C nanocomposite electrode; and (c) HR-TEM image of the Si/C nanocomposite electrode after 100th cycle.

Figure 5 shows the electrochemical impedance spectroscopy (EIS) and equivalent circuit of the $\mathrm{Si} / \mathrm{C}$ composite. EIS measurements were taken for 1st and 20th cycle in the frequency ranging from $100 \mathrm{kHz}$ to $10 \mathrm{mHz}$ and an AC signal of $10 \mathrm{mV}$ in amplitude as the perturbation. As shown in Figure 5, two semicircles were observed in between the high-frequency region to medium frequency region, which indicates the resistance caused by SEI film formation $\left(R_{\text {sei }}\right)$, and charge transfer resistance $\left(R_{c t}\right)$ between the electrode to electrolyte interface and the angled line in the low-frequency range corresponds to the ion-diffusion process within the anodes [50]. The equivalent circuit diagram (Figure 5) was used for fitting the EIS data, where $R_{S}$ is the bulk resistance raised from electrode, electrolyte, and separator; $R_{\text {sei }}$ is the resistance of the SEI film and its relevant capacitance is denoted as CPE1; $R_{c t}$ is charge transfer resistance and its relevant capacitance is denoted as CPE2; and $\mathrm{Zw}$ is the Warburg impedance [50]. As per the fitting results, the $R_{\text {sei, }}$ and $R_{c t}$ of the $\mathrm{Si} / C$ nanocomposite electrode showed about 6 and $40 \Omega$ for the initial cycle, and 5 and $17 \Omega$ for the 20th cycle, respectively. Therefore, it is obvious that the inner resistance of the electrode is small in the case of extended cycles. This result suggest that the electrode possesses a great conductive network owing to the carbon phase. Consequently, stable SEI film formation and efficient charge transport between active Si and carbon matrix during the electrochemical reaction lead to the lower internal resistance. The tight attach of Si nanoparticles in the carbon matrix is the key factor that ensured the good structural integrity and fast electronic/ionic transport during the lithiation/delithiation process, finally leading to high reversible capacity retention and good cycling stability of the $\mathrm{Si} / \mathrm{C}$ nanocomposite electrode.

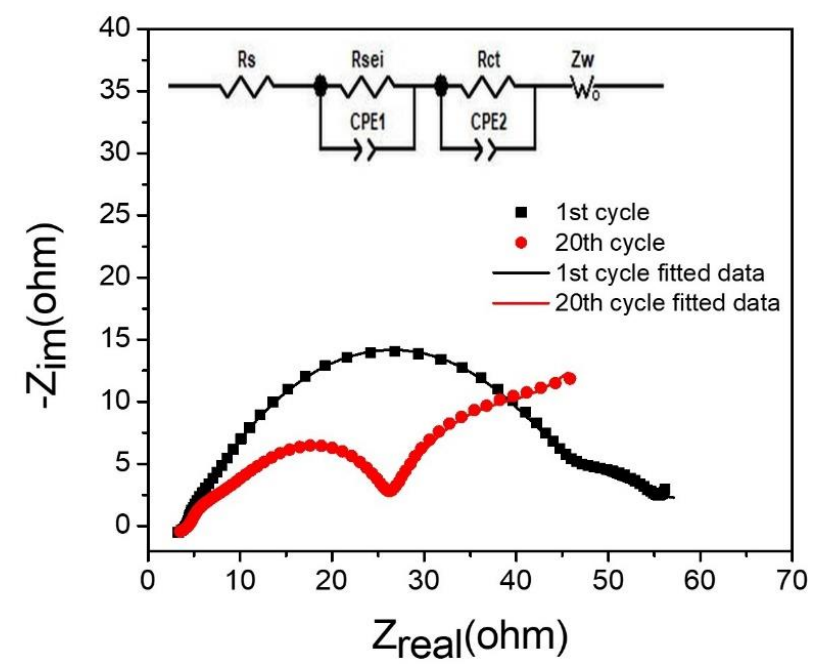

Figure 5. Electrochemical impedance spectra (EIS) and its equivalent circuit diagram for $8 \mathrm{~h}$ milled $\mathrm{Si} / \mathrm{C}$ nanocomposite powders. 


\section{Conclusions}

We have demonstrated a very simple, low-cost and large-scale production method for preparing a Si/C nanocomposite anode material through a high-energy mechanical milling and carbonization process. The XRD and TEM analyses revealed the nanocomposites comprise nano-sized Si particles in a carbon matrix phase and there were no significant contamination peaks observed. The role of the carbon layer was to form a stable solid electrolyte Interface (SEI), accommodate the Si volume changes during cycling and maintain good electrically-conducting pathways. The $\mathrm{Si} / \mathrm{C}$ nanocomposite electrode delivered a remarkable capacity of $1181 \mathrm{mAh} \mathrm{g}^{-1}$ at 100th cycle with a coulombic efficiency of $99.2 \%$. Such high capacity and coulombic efficiency were attributed to the size reduction of $\mathrm{Si}$ particle to nanometer scale and uniform distribution of nano-sized active Si particles in carbon matrix phase, which provides good mechanical integrity and electrical contact between the Si nanoparticles. Thus, the carbon coated-silicon nanocomposite prepared via a simple and cost-effective methods of high energy mechanically milling and carbonization process, is a promising candidate for high capacity anode material in the lithium ion rechargeable batteries. However, further studies are necessary to verify the suitability of $\mathrm{Si} / \mathrm{C}$ nanocomposite anode material in the lithium-ion battery full cells.

Author Contributions: Conceptualization R.M. and K.-S.L.; Methodology R.M. and W.J.C.; Investigation and Writing original draft R.M.; Writing-Review \& Editing C.L. and K.-S.L.

Funding: This research was funded by Basic Science Research Program through the National Research Foundation of Korea (NRF) the Ministry of Education (NRF-2017R1D1A1A02019022).

Conflicts of Interest: The authors declare no conflict of interest.

\section{References}

1. Blomgren, G.E. The development and future of lithium ion batteries. J. Electrochem. Soc. 2017, 164, A5019-A5025. [CrossRef]

2. Schmuch, R.; Wagner, R.; Hörpel, G.; Placke, T.; Winter, M. Performance and cost of materials for lithium-based rechargeable automotive batteries. Nat. Energy 2018, 3, 267-278. [CrossRef]

3. Cano, Z.P.; Banham, D.; Ye, S.; Hintennach, A.; Lu, J.; Fowler, M.; Chen, Z. Batteries and fuel cells for emerging electric vehicle markets. Nat. Energy 2018, 3, 279-289. [CrossRef]

4. Amalraj, S.F.; Hadar, S.; Yuliya, S.; Rao, P.T.; Ravikumar, R.; Satyanarayana, M.; Sandipan, M.; Halalay, I.C.; Shalom, L.; Boris, M.; et al. Horizons for Li-Ion batteries relevant to electro-mobility: High-specific-energy cathodes and chemically active separators. Adv. Mater. 2018, 30, 1801348. [CrossRef]

5. Lee, H.Y.; Lee, S.M. Graphite-FeSi alloy composites as anode materials for rechargeable lithium batteries. J. Power Sources 2002, 112, 649-654. [CrossRef]

6. McDowell, M.T.; Lee, S.W.; Nix, W.D.; Cui, Y. Understanding the lithiation of silicon and other alloying anodes for lithium-ion batteries. Adv. Mater. 2013, 25, 4966-4985. [CrossRef] [PubMed]

7. Zhang, W.J. Lithium insertion/extraction mechanism in alloy anodes for lithium-ion batteries. J. Power Sources 2011, 196, 877-885. [CrossRef]

8. Liu, X.H.; Liu, Y.; Kushima, A.; Zhang, S.; Zhu, T.; Li, J.; Huang, J.Y. Insitu TEM experiments of electrochemical lithiation and delithiation of individual nanostructures. Adv. Energy Mater. 2012, 2, $722-741$. [CrossRef]

9. Wu, H.; Chan, G.; Choi, J.W.; Ryu, I.; Yao, Y.; Mcdowell, M.T.; Lee, S.W.; Jackson, A.; Yang, Y.; Hu, L.; et al. Stable cycling of double-walled silicon nanotube battery anodes through solid-electrolyte interphase control. Nat. Nanotechnol. 2012, 7, 310-315. [CrossRef] [PubMed]

10. Lu, Z.; Liu, N.; Lee, H.W.; Zhao, J.; Li, W.; Li, Y.; Cui, Y. Nonfilling carbon coating of porous silicon micrometer-sized particles for high-performance lithium battery anodes. ACS Nano 2015, 9, $2540-2547$. [CrossRef] [PubMed]

11. Obrovac, M.N.; Chevrier, V.L. Alloy negative electrodes for Li-ion batteries. Chem. Rev. 2014, 114, 11444-11502. [CrossRef] [PubMed] 
12. Holtstiege, F.; Wilken, A.; Winter, M.; Placke, T. Running out of lithium? A route to differentiate between capacity losses and active lithium losses in lithium-ion batteries. Phys. Chem. Chem. Phys. 2017, 19, 25905-25918. [CrossRef] [PubMed]

13. Zhu, B.; Jin, Y.; Tan, Y.; Zong, L.; Hu, Y.; Chen, L.; Chen, Y.; Zhang, Q.; Zhu, J. Scalable production of si nanoparticles directly from low grade sources for lithium-ion battery anode. Nano Lett. 2015, 15, 5750-5754. [CrossRef] [PubMed]

14. Wang, B.; Li, X.; Qiu, T.; Luo, B.; Ning, J.; Li, J.; Zhang, X.; Liang, M.; Zhi, L. High volumetric capacity silicon-based lithium battery anodes by nanoscale system engineering. Nano Lett. 2013, 13, 5578-5584. [CrossRef] [PubMed]

15. Karki, K.; Zhu, Y.; Liu, Y.; Sun, C.F.; Hu, L.; Wang, Y.; Wang, C.; Cumings, J. Hoop-Strong Nanotubes for Battery Electrodes. ACS Nano. 2013, 7, 8295-8302. [CrossRef] [PubMed]

16. Abel, P.R.; Lin, Y.M.; Celio, H.; Heller, A.; Mullins, C.B. Improving the stability of nanostructured silicon thin film lithium-ion battery anodes through their controlled oxidation. ACS Nano 2012, 6, 2506-2516. [CrossRef] [PubMed]

17. Lv, Q.; Liu, Y.; Ma, T.; Zhu, W.; Qiu, X. Hollow structured silicon anode with stabilized solid electrolyte interphase film for lithium-ion batteries. ACS Appl. Mater. Interfaces 2015, 7, 23501-23506. [CrossRef] [PubMed]

18. Sun, W.; Hu, R.; Zhang, M.; Liu, J.; Zhu, M. Binding of carbon coated nano-silicon in graphene sheets by wet ball- milling and pyrolysis as high performance anodes for lithium-ion batteries. J. Power Sources 2016, 318, 113-120. [CrossRef]

19. Lv, P.; Zhao, H.; Wang, J.; Liu, X.; Zhang, T.; Xia, Q. Facile preparation and electrochemical properties of $\mathrm{SiO}_{2} / \mathrm{C}$ composite as anode material for lithium ion batteries. J. Power Source 2013, 237, 291-294. [CrossRef]

20. Chen, X.; Gerasopoulos, K.; Guo, J.; Brown, A.; Wang, C.; Ghodssi, R.; Culver, J.N. Virus-enabled silicon anode for lithium-ion batteries. ACS Nano 2010, 4, 5366-5372. [CrossRef] [PubMed]

21. Kummer, M.; Badillo, J.P.; Schmitz, A.; Bremes, H.G.; Winter, M.; Schulz, C.; Wiggers, H. Silicon/polyaniline nanocomposites as anode material for lithium ion batteries. J. Electrochem. Soc. 2013, 161, A40-A45. [CrossRef]

22. Magasinski, A.; Zdyrko, B.; Kovalenko, I.; Hertzberg, B.; Burtovyy, R.; Huebner, C.F.; Fuller, T.F.; Luzinov, I.; Yushin, G. Toward efficient binders for Li-ion battery Si-based anodes: Polyacrylic acid. ACS Appl. Mater. Interfaces 2010, 2, 3004-3010. [CrossRef] [PubMed]

23. Xu, C.; Lindgren, F.; Philippe, B.; Gorgoi, M.; Bjorefors, F.; Edstrom, K.; Gustafsson, T. Improved performance of the silicon anode for li-ion batteries: Understanding the surface modification mechanism of fluoroethylene carbonate as an effective electrolyte additive. Chem. Mater. 2015, 27, 2591-2599. [CrossRef]

24. Fan, X.Y.; Ke, F.S.; Wei, G.Z.; Huang, L.; Sun, S.G. Sn-Co alloy anode using porous Cu as current collector for lithium ion battery. J. Alloys Compd. 2009, 476, 70-73. [CrossRef]

25. Zhang, T.; Gao, J.; Fu, L.J.; Yang, L.C.; Wu, Y.P.; Wu, H.Q. Natural graphite coated by Si nanoparticles as anode materials for lithium ion batteries. J. Mater. Chem. 2007, 17, 1321-1325. [CrossRef]

26. Xiang, H.; Zhang, K.; Ji, G.; Lee, J.Y.; Zou, C.; Chen, X.; Wu, J. Graphene/nanosized silicon composites for lithium battery anodes with improved cycling stability. Carbon 2011, 49, 1787-1796. [CrossRef]

27. Fan, X.; Zou, L.; Zheng, Y.P.; Kang, F.Y.; Shen, W.C. Electrospinning preparation of nanosilicon/disordered carbon composite as anode materials in li-ion battery. Electrochem. Solid-State Lett. 2009, 12, A199-A201. [CrossRef]

28. Zhou, Z.B.; Xu, Y.H.; Liu, W.G.; Niu, L.B. High capacity Si/DC/MWCNTs nanocomposite anode materials for lithium ion batteries. J. Alloys Compd. 2010, 493, 636-639. [CrossRef]

29. Yen, Y.C.; Chao, S.C.; Wu, H.C.; Wu, N.L. Study on Solid-Electrolyte-Interphase of Si and C-Coated Si Electrodes in Lithium Cells. J. Electrochem. Soc. 2009, 156, A95-A102. [CrossRef]

30. Holzapfel, M.; Buqa, H.; Scheifele, W.; Novak, P.; Petrat, F.M. A new type of nano-sized silicon/carbon composite electrode for reversible lithium insertion. Chem. Commun. 2005, 12, 1566-1568. [CrossRef] [PubMed]

31. Wilson, A.M.; Reimers, J.N.; Fuller, E.W.; Dahn, J.R. Lithium insertion in pyrolyzed siloxane polymers. Solid State Ion. 1994, 74, 249-254. [CrossRef] 
32. Liu, Y.; Hanai, K.; Horikawa, K.; Imanishi, N.; Hirano, A.; Takeda, Y. Electrochemical characterization of a novel Si-graphite- $\mathrm{Li}_{2.6} \mathrm{Co}_{0.4} \mathrm{~N}$ composite as anode material for lithium secondary batteries. Mater. Chem. Phys. 2004, 89, 80-84. [CrossRef]

33. Guo, Z.P.; Milin, E.; Wang, J.Z.; Chen, J.; Liu, H.K. Silicon/disordered carbon nanocomposites for lithium-ion battery anodes. J. Electrochem. Soc. 2005, 152, A2211-A2216. [CrossRef]

34. Hasegawa, T.; Mukai, S.R.; Shirato, Y.; Tamon, H. Preparation of carbon gel microspheres containing silicon powder for lithium ion battery anodes. Carbon 2004, 42, 2573-2579. [CrossRef]

35. Wen, Z.Y.; Yang, X.L.; Huang, S.H. Composite anode materials for Li-ion batteries. J. Power Sources 2007, 174, 1041-1045. [CrossRef]

36. Patel, P.; Kim, I.S.; Kumta, P.N. Nanocomposites of silicon/titanium carbide synthesized using high-energy mechanical milling for use as anodes in lithium-ion batteries. Mater. Sci. Eng. B 2005, 116, 347-352. [CrossRef]

37. Casimir, A.; Zhang, H.; Ogoke, O.; Amine, J.C.; Lu, J.; Wu, G. Silicon-based anodes for lithium-ion batteries: Effectiveness of materials synthesis and electrode preparation. Nano Energy 2016, 27, 359-376. [CrossRef]

38. Chan, C.K.; Ruffo, R.; Hong, S.S.; Cui, Y. Surface chemistry and morphology of the solid electrolyte interphase on silicon nanowire lithium-ion battery anodes. J. Power Sources 2009, 189, 1132-1140. [CrossRef]

39. McDowell, M.T.; Ryu, I.; Lee, S.W.; Wang, C.; Nix, W.D.; Cui, Y. Studying the kinetics of crystalline silicon nanoparticle lithiation with in situ transmission electron microscopy. Adv. Mater. 2012, 24, 6034-6041. [CrossRef] [PubMed]

40. Bruce, P.G.; Scrosati, B.; Tarascon, J.M. Nanomaterials for rechargeable lithium batteries. Angew. Chem. Int. Ed. 2008, 47, 2930-2946. [CrossRef] [PubMed]

41. Yoshio, M.; Kugino, S.; Dimov, N. Electrochemical behaviors of silicon based anode material. J. Power Sources 2006, 153, 375-379. [CrossRef]

42. Ng, S.H.; Wang, J.; Wexler, D.; Chew, S.Y.; Liu, H.K. Amorphous carbon-coated silicon nanocomposites: A low-temperature synthesis via spray pyrolysis and their application as high-capacity anodes for lithium-ion batteries. J. Phys. Chem. C 2007, 111, 11131-11138. [CrossRef]

43. Gu, P.; Cai, R.; Zhou, Y.; Shao, Z. Si/C composite lithium-ion battery anodes synthesized from coarse silicon and citric acid through combined ball milling and thermal pyrolysis. Electrochim. Acta 2010, 55, 3876-3883. [CrossRef]

44. Datta, M.K.; Maranchi, J.; Chung, S.J.; Epur, R.; Kadakia, K.; Jampani, P.; Kumta, P.N. Amorphous silicon-carbon based nano-scale thin film anode materials for lithium ion batteries. Electrochim. Acta 2011, 56, 4717-4723. [CrossRef]

45. Cui, L.F.; Ruffo, R.; Chan, C.K.; Peng, H.; Cui, Y. Crystalline-amorphous core-shell silicon nanowires for high capacity and high current battery electrodes. Nano Lett. 2008, 9, 491-495. [CrossRef] [PubMed]

46. Kim, I.S.; Blomgren, G.E.; Kumta, P.N. Si-SiC nanocomposite anodes synthesized using high-energy mechanical milling. J. Power Sources 2004, 130, 275-280. [CrossRef]

47. Datta, M.K.; Kumta, P.N. In situ electrochemical synthesis of lithiated silicon-carbon based composites anode materials for lithium ion batteries. J. Power Sources 2009, 194, 1043-1052. [CrossRef]

48. Wang, X.L.; Han, W.Q. Graphene enhances Li storage capacity of porous single-crystalline silicon nanowires. ACS Appl. Mater. Interfaces 2010, 2, 3709-3713. [CrossRef] [PubMed]

49. Sourice, J.; Quinsac, A.; Leconte, Y.; Sublemontier, O.; Porcher, W.; Haon, C.; Bordes, A.; De Vito, E.; Boulineau, A.; Jouanneau Si Larbi, S.; et al. One-step synthesis of Si@C nanoparticles by laser pyrolysis: High-capacity anode material for lithium-ion batteries. ACS Appl. Mater. Interfaces 2015, 7, 6637-6644. [CrossRef] [PubMed]

50. Haregewoin, A.M.; Leggesse, E.G.; Jiang, J.C.; Wang, F.M.; Hwang, B.J.; Lin, S.D. Comparative study on the solid electrolyte interface formation by the reduction of alkyl carbonates in lithium ion battery. Electrochim. Acta 2014, 136, 274-285. [CrossRef]

(C) 2018 by the authors. Licensee MDPI, Basel, Switzerland. This article is an open access article distributed under the terms and conditions of the Creative Commons Attribution (CC BY) license (http:/ / creativecommons.org/licenses/by/4.0/). 